\title{
Tuberculous Mycotic Aneurysm of Common Iliac Artery Secondary from Ureteric Tuberculosis: The First Case Report and Review of the Literature
}

\author{
Patchara Paraksa, MD, Benjawan Skulsujirapa, MD, and Chusana Suankratay, MD, PhD
}

Extrapulmonary involvement of tuberculosis occurs in $10-40 \%$ of reported cases. However, tuberculous mycotic aneurysm is very rare. We report herein tuberculous mycotic aneurysm of left common iliac artery secondary from ureteric tuberculosis in a 63-year-old man who presented with left flank pain for 1 month, and review the literature of all reported cases of tuberculous aneurysm of iliac artery.

Keywords: tuberculous mycotic aneurysm, common iliac artery, ureteric tuberculosis

\section{Introduction}

Tuberculosis, an infectious disease with substantial morbidity and mortality, can cause a wide variety of clinical spectrum from acute to chronic and mild to fulminant course, and affect different organs. Tuberculosis mostly affects the lungs, but other organs can be involved. Most extrapulmonary tuberculosis are pleural and lymph node. Vascular and genitourinary involvement are very rare complications of tuberculosis. There are sparse reports tuberculous mycotic aneurysms of aorta in the literature, ${ }^{1,2)}$ and even fewer of iliac artery. ${ }^{3-8)}$ We report herein tuberculous mycotic aneurysm of left common iliac artery secondary from ureteric tuberculosis in a 63-year-old man who presented with left flank pain for 1 month, and review the literature of all reported cases of tuberculous aneurysm of iliac artery.

Division of Infectious Diseases, Department of Internal Medicine, Faculty of Medicine, Chulalongkorn University, Bangkok, Thailand

Received: March 28, 2017; Accepted: May 9, 2017

Corresponding author: Patchara Paraksa, MD. Division of Infectious Diseases, Department of Internal Medicine, King Chulalongkorn Memorial Hospital, 1873 Rama IV Rd., Pathumwan, Bangkok 10330, Thailand

Tel: +66-2-256-4578, Fax: +66-2-256-4578

E-mail: patcharaparaksa84@gmail.com

\section{Case Report}

A 63-year-old Thai male, living in Bangkok, with hypertension and old cerebrovascular accident presented with progressive left flank pain, radiating to the left lower quadrant of abdomen for 1 month. These symptoms were preceded by a 1-month course of low-grade fever, loss of appetite, fatigability, and weight loss of $9 \mathrm{~kg}$. Further inquiry revealed no contact with tuberculosis. Physical examination revealed a body temperature of 38.4 degree celcius, fine crepitation at right lung, and left flank tenderness with negative psoas sign. A complete blood count analysis showed white blood cell count of 12,360 cells $/ \mu \mathrm{L}$ (neutrophil $86 \%$, lymphocyte 14\%), a hemoglobin level of $12.7 \mathrm{~g} / \mathrm{dL}$, and a platelet count of 274,000 cells $/ \mu \mathrm{L}$. The serum level of C-reactive protein (CRP) and erythrocyte sedimentation rate (ESR) were $35 \mathrm{mg} / \mathrm{L}$ and $66 \mathrm{~mm} / \mathrm{hr}$ respectively. Other routine blood chemistries were unremarkable. Urinalysis showed white blood cells of 5-10/ high-power field (HPF) and red blood cells of 5-10/HPF. The HIV serology was non-reactive and chest radiogram revealed reticulonodular infiltration at right middle lung (RML) and right lower lung (RLL). Computed tomogram (CT) demonstrated multifocal irregular consolidations involving mainly superior segment of RLL and lateral segment of RML, large left iliac artery aneurysm, $6.4 \times 6.4 \times 5.7 \mathrm{~cm}$, surrounded by inflammatory tissue, extending from the aortic bifurcation to left common iliac artery, and intravenous pyelogram (IVP) showing left ureterohydronephrosis due to tapered narrowing at the middle portion of the left ureter (Fig. 1). A bronchoscopy was performed, and bronchoalveolar lavage fluid culture and polymerase chain reaction (PCR) test were positive for Mycobacterium tuberculosis that was susceptible to all first-line antituberculous agents. Urine acid-fast bacilli was negative, but PCR test was positive for M. tuberculosis complex. Therefore, a final diagnosis of disseminated tuberculosis with pulmonary, left ureter, and left common iliac artery involvement was made. The treatment included the successful bypassing the ureteral obstruction with a ureteric double-J stent, endovascular aneurysm repair 
(EVAR) of the terminal aortic bifurcation in continuity with the left common iliac artery, and a standard 6-month regimen of antituberculosis therapy (2 months of $300 \mathrm{mg}$ isoniazid, $450 \mathrm{mg}$ rifampin, $1,250 \mathrm{mg}$ pyrazinamide, and $1,000 \mathrm{mg}$ ethambutol daily and an additional 4 months of $300 \mathrm{mg}$ isoniazid and $600 \mathrm{mg}$ rifampin daily). The patient gradually improved and was discharged home 1 month after hospitalization and the 3-month follow-up CT revealed a decrease in the size of the left iliac artery

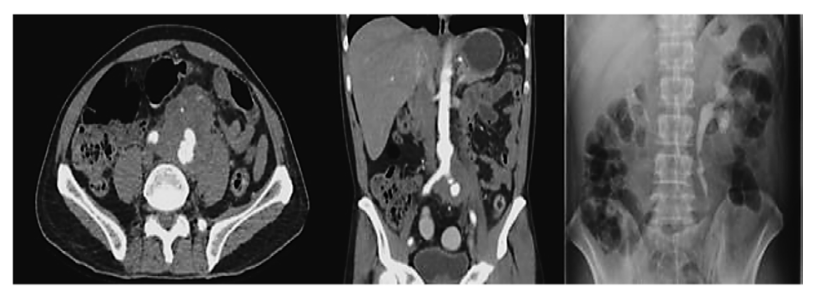

Fig. 1 Computed tomogram showing a large left common iliac artery aneurysm surrounded by inflammatory tissue and intravenous pyelogram showing left ureterohydronephrosis.

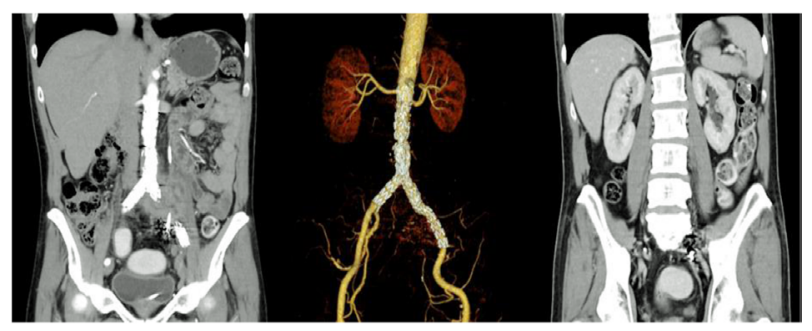

Fig. 2 Computed tomogram showing a decrease in the size of the left iliac artery aneurysm without evidence of hydronephrosis. aneurysm, $3.3 \times 3.9 \times 4.1 \mathrm{~cm}$, without evidence of hydronephrosis (Fig. 2). He was doing well when last seen 6 months after treatment.

\section{Discussion}

Tuberculous mycotic aneurysm of common iliac artery is very rare, but potentially fatal. Long and colleagues ${ }^{2}$ described the 3 possible mechanisms that the tubercle bacilli could reach the arterial wall: 1) the commonest was probably due to the direct extension from infected contiguous tissue including the paraarterial lymph nodes, lung, mediastinum, pleura, pericardium, vertebra, or paraspinal muscle, 2) the hematogenous dissemination from the distant infection site, and 3) the lymphangitic and venous spread from the infected regional lymph node and local organ. Most patients with tuberculous mycotic aneurysm present with sudden abdominal pain with and without hemodynamic shock due to the rupture or dissection of the aneurysm. ${ }^{9)}$ To date, there have been 6 patients with tuberculous mycotic aneurysm of common iliac artery (Table 1). The median age of these patients is 55 years (Interquartile range: $31.5-72.0$ years). Three $(50 \%)$ patients are male sex. The nationality of patients is South Korea, South Africa, Guinea, Japan, Negro, and the United States. The duration of illness ranges from 3 hours to 6 months. The aneurysm locates at the right site of common iliac artery in $5(83 \%)$ patients. The most common associated tuberculosis at other sites is the lung and lymph node $(3$ patients each, $50 \%$ ), followed by the pleura, pericardium, aorta, bone, peritoneum, liver, spleen, small bowel, and

Table 1 A summary of 6 reported cases of tuberculous mycotic aneurysm of common iliac artery

\begin{tabular}{|c|c|c|c|c|c|c|c|}
\hline Case & $\begin{array}{c}\text { Age } \\
\text { (year)/sex }\end{array}$ & $\begin{array}{l}\text { Nation/ } \\
\text { comorbidity }\end{array}$ & $\begin{array}{l}\text { Clinical presentation/ } \\
\text { duration of illness }\end{array}$ & $\begin{array}{l}\text { ClA aneurysm } \\
\text { side }\end{array}$ & $\begin{array}{l}\text { Associated TB at } \\
\text { other sites }\end{array}$ & Surgery/medical treatment & $\begin{array}{l}\text { Follow-up } \\
\text { (months)/ } \\
\text { outcome }\end{array}$ \\
\hline $1^{3)}$ & 78/M & $\begin{array}{l}\text { South Korea/ASO, } \\
\text { TCC }\end{array}$ & $\begin{array}{l}\text { Accidental finding during } \\
\text { follow-up CT/unknown } \\
\text { duration }\end{array}$ & Right & No & $\begin{array}{l}\text { Debridement and drainage } \\
\text { and EVAR/HRZE }\end{array}$ & 5/improvement \\
\hline $2^{4)}$ & $12 / F$ & South Africa/no & $\begin{array}{l}\text { Abdominal pain for } 3 \text { weeks, } \\
\text { and iliac fossa pain for few } \\
\text { hours }\end{array}$ & Right & Descending AA & $\begin{array}{l}\text { Resection, revascularization } \\
\text { by aortofemoral bypass } \\
\text { graft, HRZE }\end{array}$ & 9/cure \\
\hline $3^{6)}$ & 38/M & $\begin{array}{l}\text { Guinea/chronic } \\
\text { viral hepatitis B }\end{array}$ & $\begin{array}{l}\text { Fever for } 6 \text { months, and } \\
\text { abdominal pain for } 2 \text { days }\end{array}$ & Right & $\begin{array}{l}\text { Abdominal and mediastinal } \\
\text { lymph node, lung, peri- } \\
\text { cardial, bone and joint }\end{array}$ & $\begin{array}{l}\text { Resection with ligature of CIA } \\
\text { and reconstruction of aortic } \\
\text { bifurcation/HRZE }\end{array}$ & 6/cure \\
\hline $4^{5)}$ & $59 / F$ & $\begin{array}{l}\text { Japan/old } \\
\text { pulmonary TB }\end{array}$ & $\begin{array}{l}\text { Massive hematemesis and } \\
\text { melena for } 1 \text { day }\end{array}$ & Right & Pleura, peritoneum, ileum & $\begin{array}{l}\text { Extraanatomic bypass graft } \\
\text { between left and right FA/no }\end{array}$ & 2 days/death \\
\hline $5^{8)}$ & $51 / \mathrm{M}$ & Negro/CAD, CVA & $\begin{array}{l}\text { Left flank and lower abdomi- } \\
\text { nal pain for } 3 \text { hours }\end{array}$ & Left & $\begin{array}{l}\text { Lung, intraabdominal } \\
\text { lymph node, left ureter }\end{array}$ & No/no & 1day/death \\
\hline 67) & $70 / F$ & US/none & $\begin{array}{l}\text { Epigastrium pain for } 5 \\
\text { months, and massive } \\
\text { hematemesis and melena } \\
\text { for } 1 \text { day }\end{array}$ & Right & $\begin{array}{l}\text { Lung, bronchial lymph } \\
\text { node, duodenum, liver, } \\
\text { spleen }\end{array}$ & No/no & 1 day/death \\
\hline
\end{tabular}

M: male; F: female; TB: tuberculosis; ASO: atherosclerosis obliterans; TCC: transitional cell carcinoma; CT: computed tomogram; CIA: common iliac artery; FA: femoral artery; EVAR: endovascular aneurysm repair; H: isoniazid; R: rifampin; Z: pyrazinamide; E: ethambutol; AA: abdominal aorta; CAD: coronary artery disease; CVA: cerebrovascular accident; US: the United States 
ureter (1 patient each, $16.7 \%$ ). Among 6 patients, 3 underwent curative surgery including aneurysm resection $(2$ patients) and fistulectomy (1 patient), 1 patient underwent EVAR, and 2 patients expired within few days due to the aneurysm rupture before making the definite diagnosis. Two patients cured with a range of follow-up of 6 to 9 months. One patient improved but lost to follow-up after 5 months of treatment. There are 3 in-hospital mortalities due to profound shock.

In our patient, we postulate that the tubercle bacilli from the lungs disseminated hematogenously from the lungs to the left kidney, were excreted in the urine and lodged to the distal ureter, and spread to the adjacent left common iliac artery causing the mycotic aneurysm. The ureterohydronephrosis demonstrated by the imagings is caused by the luminal obstruction, not from the extraluminal compression. In contrast, the previous case report showed that the ureteral obstruction was secondary from the rupture of the iliac aneurysm. ${ }^{8)}$

The clinical diagnosis of tuberculous mycotic aneurysm is very difficult; there should be the high index of suspicion when taking care of all patients presented with fever and sudden or unexplained abdominal or flank or back pain. Due to the advance in imaging technology, either CT or magnetic resonance angiogram is able to demonstrate the presence of aneurysm and complications of aorta and its branches. To date, there have been no randomized controlled study comparing the medical treatment with and without surgical intervention. However, most studies showed that all survived patients, besides from antituberculous treatment, underwent surgical intervention which includes aneurysm resection with in vascular graft, aneurysm exclusion with bypass graft, and EVAR. ${ }^{10)}$ Endovascular treatment with stent graft or coil can be proposed in patients at high risk for surgery or with a minimal amount of infected tissue. Our patient survived with both surgical and medical treatment.

\section{Conclusion}

We report the first case of tuberculous mycotic aneurysm of common iliac artery secondary from the ureteric tuberculosis, and review the English literature.

\section{Disclosure Statement}

All authors have no conflict of interest.

\section{Author Contributions}

Study conception: PP

Data collection: PP, BS

Analysis: PP, BS, CS

Investigation: $\mathrm{PP}, \mathrm{CS}$

Writing: PP, CS

Funding acquisition: PP

Critical review and revision: all authors

Final approval of the article: all authors

Accountability for all aspects of the work: all authors

\section{References}

1) Hussein H, Azizi Z. Tuberculous aortic pseudoaneurysm treated with in situ silver-impregnated vascular inlay graft. Asian J Surg 2008; 31: 87-9.

2) Long R, Guzman R, Greenberg H, et al. Tuberculous mycotic aneurysm of the aorta: review of published medical and surgical experience. Chest 1999; 115: 522-31.

3) Youn JK, Kim SM, Han A, et al. Surgical treatment of infected aortoiliac aneurysm. Vasc Spec Int 2015; 31: 41-6.

4) Cox SG, Naidoo NG, Wood RJ, et al. Tuberculous iliac artery aneurysm in a pediatric patient. J Vasc Surg 2013; 57 : 834-6.

5) Iwamoto I, Takechi Y, Tomoe H, et al. Right common iliac arterio-intestinal fistula caused by tubercular peritonitis: report of a case. Surg Today 1993; 23: 78-80.

6) Bachmeyer C, Blanchard M, Brian E, et al. Tuberculous pseudoaneurysm of the common iliac artery. Int J Infect Dis 2010; 14: e541-2.

7) Reed WS. Tuberculous erosion of the right common iliac artery with rupture into the duodenum; a case report and further tabular review of rupture of the aorta into the gastrointestinal tract. Surgery 1955; 38: 729-37.

8) McCune WR, Galleher E, Oster W. Ureteral obstruction following rupture of an iliac artery secondary to tuberculous arteritis. J Urol 1965; 94: 391-4.

9) Gornik HL, Creager MA. Aortitis. Circulation 2008; 117: 3039-51.

10) Dogan S, Memis A, Kale A, et al. Endovascular stent graft placement in the treatment of ruptured tuberculous pseudoaneurysm of the descending thoracic aorta: case report and review of the literature. Cardiovasc Intervent Radiol 2009; 32: $572-6$. 